\title{
D-D dimer levels in patients with sickle cell disease during bone pain crises and in the steady state
}

This article was published in the following Dove Press journal:

Pathology and Laboratory Medicine International

18 May 2012

Number of times this article has been viewed

\author{
Eyitayo Emmanuel Fakunle' \\ Kapoona Iwara Ibiang Eteng ${ }^{2}$ \\ Wuraola Adebola Shokunbi² \\ 'Department of Pathology, King \\ Edward VII Memorial Hospital, \\ Bermuda; ${ }^{2}$ Department of Hematology, \\ University College Hospital, Ibadan, \\ Nigeria
}

Objective: To determine the presence of ongoing thrombosis by measuring the D-D dimer levels in bone pain crises (BPCs) and in the steady state of patients with sickle cell disease, comparing these levels with those in individuals with normal hemoglobin (HbAA) in southwest Nigeria.

Study design, patients, and methods: The study design involved 38 patients with homozygous sickle cell anemia (HbSS) and 78 adults with the HbAA phenotype, seen at the Hematology Day Care and Accident and Emergency units of the University College Hospital, Ibadan, Nigeria. The TintElize kit was used to quantitatively determine human D-D dimer levels in the plasma with enzyme immunoassay.

Results: The mean D-D dimer level measured of the 78 individuals with HbAA was $73.59 \mathrm{ng} / \mathrm{mL}$. The mean D-D dimer level of the patients with HbSS during BPCs was $4002.40 \mathrm{ng} / \mathrm{mL}$, while the mean level in the same patients in the steady state measured 6 weeks after their BPCs, with no other painful crisis episode before the sample was collected, was $1320.00 \mathrm{ng} / \mathrm{mL}$.

Conclusion: This study demonstrated a significant increase in the D-D dimer levels of patients with $\mathrm{HbSS}$ in the steady state, when compared with those of individuals with HbAA of the same age and sex distribution. There was also an approximate threefold increase in the D-D dimer levels in the same patients with HbSS during BPCs. This confirms the activation of coagulation and fibrinolytic systems in patients with HbSS in the steady state, which is further escalated during BPCs. A multicenter study on the use of anticoagulants in BPCs in patients with sickle cell disease is required.

Keywords: anticoagulant, dimer, sickle cell disease, BPC, Nigeria, chronic hemolytic anemia

\section{Introduction}

Patients with homozygous sickle cell anemia (HbSS) are heterogeneous with respect to clinical, rheological, and hematological parameters, and attempts to demonstrate a correlation among these variables have produced conflicting results due to the difficulty in defining clinical severity in these patients. In the past, microvascular occlusion by the sludge of sickle red blood cells (RBCs) was thought to be the only mechanism responsible for the painful crises and subsequent damage to various end organs. However, there is increasing evidence that sickle cell disease (SCD) - as well as other chronic hemolytic anemias, such as $\beta$ thalassemia, paroxysmal nocturnal hemoglobinuria, autoimmune hemolytic anemia, and unstable hemoglobinopathies - is characterized by a hypercoagulable state. ${ }^{1,2}$ Activation of the coagulation and fibrinolytic systems appears to play a role in the complex physiologic interactions of SCD. ${ }^{3} \mathrm{SCD}$ is characterized by $\mathrm{RBC}$ membrane abnormalities, with abnormal exposure of phosphatidylserine, ${ }^{1}$ 
leading to sticky red cells and sludging. Hemostatic disorders in patients with SCD are typified by a hypercoagulable state, and plasma D-D dimer levels have been shown to correlate with the frequency and severity of painful vasoocclusive crises (VOCs) in $\mathrm{SCD}^{4}$; however, the role of coagulation mechanisms in the genesis of VOCs is still inconclusive. First, science must further elucidate the hemostatic status of patients with SCD.

\section{Study design and patients}

This was a prospective cross-sectional, hospital-based study. Patients with homozygous HbSS disease in bone pain crises (BPCs) presenting at the Hematology Day Care and Accident and Emergency Units, University College Hospital, Ibadan, Nigeria, during the period of the study were included. Ethical approval for this study was obtained from the Institutional Review Board, College of Medicine, University of Ibadan, Ibadan, Nigeria.

Patients with $\mathrm{HbSS}$ as well as other medical conditions not directly attributable to the disease (eg, renal/liver failure), other types of hemoglobinopathies and patients with $\mathrm{HbSS}$ presenting with other types of VOC (eg, abdominal crises, priapism, and acute chest syndrome) were excluded from the study. A total of 38 patients constituted the study population group while $78 \mathrm{HbAA}$ individuals in the same age range served as the control subjects. Blood samples were taken from both groups on presentation at the hospital. Six weeks after the BPC, blood samples were taken again from the patient group which served as the auto-control.

\section{Methods}

Citrated plasma samples $(3.2 \%$ citrate) from the patients and control subjects were stored frozen at $-30^{\circ} \mathrm{C}$. The D-D dimer levels were estimated every 2 months from the plasma samples using the TintElize ${ }^{\circledR}$ enzyme immunoassay (Biopool, Umea, Sweden). This immunoassay uses the double antibody principle. The plasma sample was added to a microtest well, which was coated with MA-8D3, a monoclonal antibody against D-D dimer. After an incubation period of 30 minutes, which is sufficient to allow $>85 \%$ of the D-D dimer to bind to the coated antibodies, a horseradish peroxidase-labeled Fab fragment of anti-D-D dimer immunoglobulin $G$ was added. The horseradish peroxidase-labeled anti-D-D dimer was allowed to react with the adsorbed D-D dimer. Then the well was emptied and washed to remove unbound conjugate. Following this, peroxidase substrate $\left(\mathrm{OPD} / \mathrm{H}_{2} \mathrm{O}_{2}\right)$ was added. The quantity of yellow that developed was measured with the enzyme-linked immunosorbent assay reader. The yellow intensity is directly proportional to the amount of D-D dimer present in the sample.

\section{Results}

A total of 38 patients with $\mathrm{HbSS}$, age range 17-41 years old, were enrolled in this study: 18 (47\%) men and $20(53 \%)$ women. Only $11(28.9 \%)$ of the patients had BPCs more than 6 weeks before the BPC episode they had at the time of the study. Thirty-four $(89.5 \%)$ of the patients had moderately severe BPCs (pain grade of 5-9). The BPC in 31 (81.6\%) of the patients started within 4 days of the study, while three (7.9\%) of the patients presented 10-14 days after onset of the crises.

The mean D-D dimer level measured of the 78 individuals with HbAA (Table 1) was $73.59 \mathrm{ng} / \mathrm{mL}$ (range $=10-430 \mathrm{ng} / \mathrm{mL}$ ). D-D dimer values $<500 \mathrm{ng} / \mathrm{mL}$ were considered normal according to the D-D dimer levels determined with the TintElize enzyme immunoassay.

Table 2 shows the D-D dimer levels and the frequency distribution of the patients with $\mathrm{HbSS}$ during BPCs and the steady state 6 weeks after the BPC episode. The mean value of the $\mathrm{D}-\mathrm{D}$ dimer level measured during $\mathrm{BPC}$ was $4002.40 \mathrm{ng} / \mathrm{mL}$ (range $=230-12,480 \mathrm{ng} / \mathrm{mL})$, while that measured in the same patients with $\mathrm{HbSS}$ in the steady state 6 weeks after the BPC episode with no other episode of painful crises before the sample was collected was $1320.00 \mathrm{ng} / \mathrm{mL}$ (range $=140-7610 \mathrm{ng} / \mathrm{mL})$. Eighteen $(47.4 \%$ ) of the patients with HbSS during BPCs had D-D dimer levels $>3000 \mathrm{ng} / \mathrm{mL}$, while $36(94.7 \%)$ of the patients with HbSS 6 weeks after a major BPC had levels $<3000 \mathrm{ng} / \mathrm{mL}$.

Four of the patients with HbSS presented to the hospital again with bone pain before the end of the sixth week. Their D-D dimer levels were estimated for the second episode and the repeat sampling 6 weeks with no further BPC episode in between. The patients' D-D dimer levels are shown in Figure 1.

Table I D-D dimer levels of individuals with HbAA

\begin{tabular}{lll}
\hline $\begin{array}{l}\text { D-D dimmer levels } \\
(\mathbf{n g} / \mathbf{m L})\end{array}$ & Number & Percentage \\
\hline $0-49$ & 7 & 9.0 \\
$50-99$ & 19 & 24.4 \\
$100-149$ & 9 & 11.5 \\
$150-199$ & 1 & 1.3 \\
$200-249$ & 10 & 12.8 \\
$250-299$ & 11 & 14.1 \\
$300-349$ & 12 & 15.4 \\
$350-399$ & 6 & 7.6 \\
$400-449$ & 3 & 3.9 \\
Total & 78 & 100.0 \\
\hline
\end{tabular}


Table 2 D-D dimer levels of patients with HbSS

\begin{tabular}{lll}
\hline $\begin{array}{l}\text { D-D dimer } \\
\text { levels } \\
\text { (ng/mL) }\end{array}$ & $\begin{array}{l}\text { Number (percentage) } \\
\text { during BPCs }\end{array}$ & $\begin{array}{l}\text { Number (percentage) } \\
\text { in the steady state }\end{array}$ \\
\hline $0-499$ & $2(5.3)$ & $8(21.1)$ \\
$500-999$ & $5(13.2)$ & $12(31.6)$ \\
$1000-2999$ & $13(34.2)$ & $16(42.1)$ \\
$3000-4999$ & $7(18.4)$ & $1(2.6)$ \\
$5000-6999$ & $4(10.5)$ & $0(0.0)$ \\
$7000-8999$ & $4(10.5)$ & $1(2.6)$ \\
$9000-10,999$ & $1(2.6)$ & $0(0.0)$ \\
$11,000-12,999$ & $2(5.3)$ & $0(0.0)$ \\
Total & $38(100.0)$ & $38(100)$ \\
\hline
\end{tabular}

Note: $P<0.001$.

Abbreviation: BPCs, bone pain crises.

\section{Discussion}

SCD presents clinically with varying severity in different population groups. In this study, there was a significant increase in the D-D dimer levels in patients with $\mathrm{HbSS}$ (mean value $=1320 \mathrm{ng} / \mathrm{mL}$ ) in the steady state compared with the D-D dimer levels of individuals with HbAA (mean value $=73.6 \mathrm{ng} / \mathrm{mL}$ ) in the same age group and sex distribution. During BPCs in the patients with HbSS, the D-D dimer levels increased by about threefold with a mean value of $4002.40 \mathrm{ng} / \mathrm{mL}(P<0.001)$. This confirms that activation of the coagulation and fibrinolytic systems in the steady state is further escalated during BPCs in individuals with $\mathrm{HbSS}$.

Normally, phosphatidylserine is found in the inner monolayer of the cell membrane, whereas choline-containing phospholipids, such as phosphatidylcholine and sphingomyelin, are located in the outer monolayer in the plasma membrane. ${ }^{5}$ Abnormal phosphatidylserine exposure functions as a recognition signal for cell removal during apoptosis of nucleated cells $^{6}$ and a docking site for enzymatic complexes involved in coagulation and anticoagulation pathways. ${ }^{3}$ External exposure of phosphatidylserine alters the adhesive properties of $\mathrm{RBCs}^{7}$ and appears to be involved in the hemostatic changes observed in hemolytic anemias, particularly SCD. ${ }^{8-11}$ The number of phosphatidylserine-positive RBCs has been reported to be significantly correlated with plasma markers of thrombin generation, such as prothrombin fragment $1+2$, D-D dimer, and plasmin-antiplasmin complexes in SCD, suggesting a significant role for RBCs in coagulation activation. ${ }^{8,9}$ Tissue factor, the principal initiator of coagulation, is abnormally expressed in circulating endothelial cells in patients with SCD. ${ }^{12}$ Microparticles released during hemolysis may be tissue factor-positive. ${ }^{13}$ Several potential mechanisms for increased tissue factor expression have been described in SCD, including ischemia-reperfusion injury, ${ }^{14}$ increased levels of soluble CD40 ligand, ${ }^{15}$ and increased heme levels. ${ }^{16}$

These observations have been most frequently noted during episodes of painful vasoocclusion, but some abnormalities have also been detected in patients with SCD during the steady state. For this reason, it has perhaps been difficult to correlate such findings with the actual severity of SCD and it has been even more difficult to define the specific role played by disordered hemostasis in clinical manifestations that are referred to as "sickle cell crises."

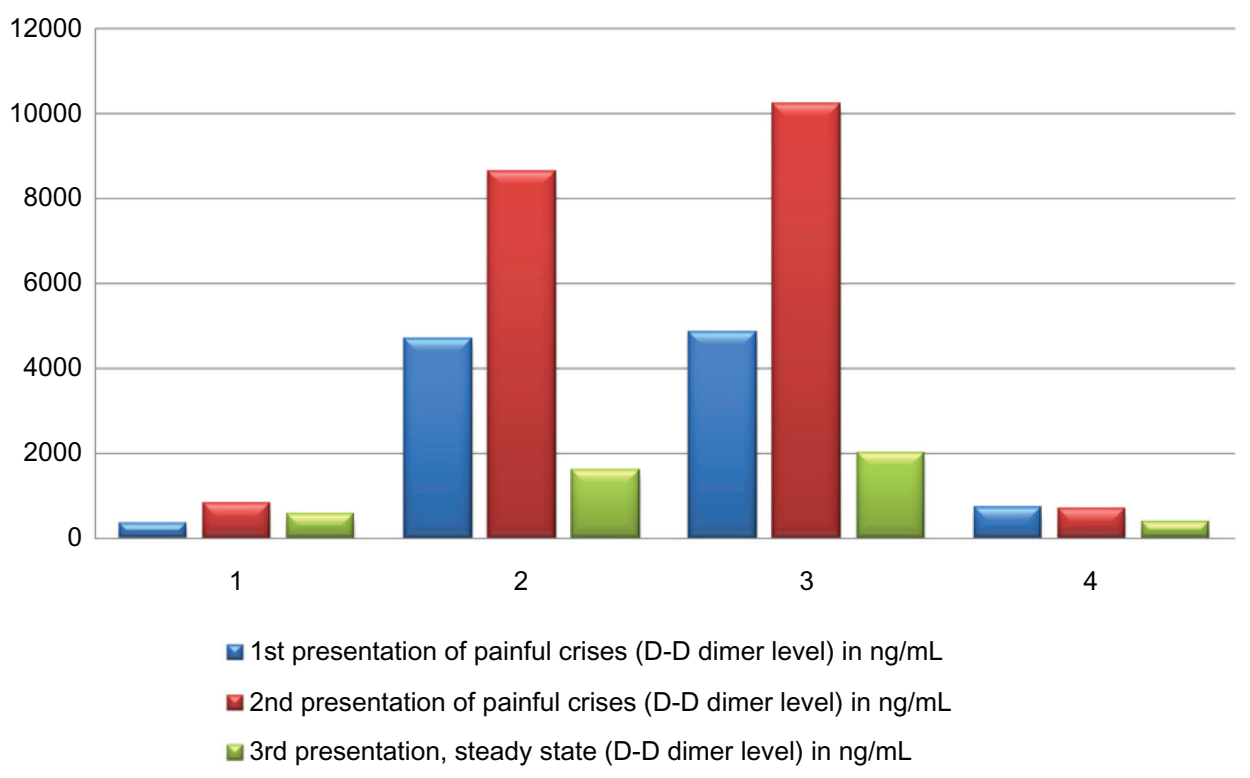

Figure I D-D dimer levels of four patients with bone pains at 6 weeks of a repeat bone pain crisis. Note: $P$ value $=0.033$. 
What role do the severity of the pain and the frequency of BPC have to play in determining the D-D dimer level at a given time? The precise level of D-D dimer circulating in the blood at a given time depends on the time elapsed since the thrombotic event, the initial size of the clot, and the rate of fibrinolysis. It is possible that the marked increase in D-D dimer levels observed in this study was due to multiple sites with varying severity of thrombi formation during BPCs in patients with HbSS. D-D dimer has a half-life of approximately 6 hours in the circulation of individuals with normal renal function. Patients with stabilized clots and who are not undergoing active fibrin deposition and plasmin activation may not have detectable D-D dimer elevations. Determining D-D dimer reflects activation of prothrombin plasminogen and of factor XIII. Thus, a direct test for circulating thrombin activity might give a clearer answer to the question of how severe the real state of coagulation activation is. ${ }^{17}$

The numerous complications of SCD that vary widely among patients are vexing for those experiencing them and their physicians. The frequency of VOCs, although of importance, cannot solely serve as a parameter of treatment efficacy; additional objective parameters are needed to effectively study and manage VOCs in SCD. ${ }^{18}$ Objective laboratory parameters that accurately reflect the vasoocclusive process in patients with SCD are needed to aid the clinician in daily assessment and management of this unpredictable disease. No single mechanism explains the vasoocclusion seen in SCD and the complexity of the process of vasoocclusion provides many possibilities for therapeutic intervention. ${ }^{19}$ The routine use of antithrombotic agents in patients with HbSS during a BPC is generally not favored. However, low-dose heparin therapy (ie, in prophylactic doses) during intractable BPC and acute chest syndrome in patients with $\mathrm{HbSS}$ have been documented to have beneficial effect.

\section{Conclusion}

This study demonstrated a significant increase in the D-D dimer levels of patients with HbSS in the steady state, when compared with those of individuals with HbAA of the same age and sex distribution. There was also an approximately threefold increase in the D-D dimer levels in the same patients with HbSS during BPCs. This confirms the activation of coagulation and fibrinolytic systems in patients with $\mathrm{HbSS}$ in the steady state, which is further escalated during BPCs. Finally, well-controlled clinical studies of therapeutic and prophylactic doses of anticoagulant use in BPCs and in other forms of vasoocclusion employing appropriate clinical endpoints with the aim of reducing the severity and duration of SCD crises are required.

\section{Disclosure}

The authors declare no conflicts of interest in this work.

\section{References}

1. Ataga KI, Cappellini MD, Rachmilewitz EA. $\beta$-thalassemia and sickle cell anaemia as paradigms of hypercoagulability. Br J Haematol. 2007;139:3-13.

2. Eldor A, Rachmilewitz EA. The hypercoagulable state in thalassemia. Blood. 2002;99:36-43.

3. Zwaal RFA, Schroit AJ. Pathophysiologic implications of membrane phospholipids asymmetry in blood cells: a review. Blood. 1997;89:1121-1132.

4. Devine DV, Kinney TR, Thomas PF. Fragment D-Dimer levels: an objective marker of vaso-occlusive crisis and other complications of sickle cell disease. Blood. 1986;68:317-319.

5. Devaux PF, Zachowski A. Maintenance and consequences of membrane phospholipid asymmetry. Chem Phys Lipids. 1994;73:107-120.

6. Fadok VA, Voelker DR, Campbell PA, Cohen JJ, Bratton DL, Henson PM. Exposure of phosphatidylserine on the surface of apoptotic lymphocytes triggers specific recognition and removal by macrophages. J Immunol. 1992;148:2207-2216.

7. Setty BN, Kulkani S, Stuart MJ. Role of erythrocyte phosphatidylserine in sickle red cell-endothelial adhesion. Blood. 2002;99:1564-1571.

8. Setty BN, Rao AK, Stuart MJ. Thrombophilia in sickle cell disease: the red cell connection. Blood. 2001;98:3228-3233.

9. Setty BN, Kulkani S, Rao AK, Stuart MJ. Fetal hemoglobin in sickle cell disease. Relationship to erythrocyte phosphatidylserine exposure and coagulation activation. Blood. 2000;96:1119-1124.

10. Borenstain-Ben Yashar V, Barenholz Y, Hy-Am E, Rachmilewitz EA, Eldor A. Phosphatidylserine in the outer leaflet of red blood cells from $\beta$-thalassemia patients may explain the chronic hypercoagulable state and thrombotic episodes. Am J Hematol. 1993;44:63-65.

11. Wandersee NJ, Lee JC, Deveau SA, Barker JE. Reduced incidence of thrombosis in mice with hereditary spherocytosis following neonatal treatment with normal hematopoietic cells. Blood. 2001;97: 3972-3975.

12. Key NS, Slungaard A, Dandelet L, et al. Whole blood tissue factor procoagulant activity is elevated in patients with sickle cell disease. Blood. 1998;91:4216-4223.

13. Shet AS, Aras O, Gupta K, et al. Sickle blood contains tissue factorpositive microparticles derived from endothelial cells and monocytes. Blood. 2003;102:2678-2683.

14. Solovey A, Kollander R, Shet A, et al. Endothelial cell expression of tissue factor in sickle mice is augmented by hypoxia/reoxygenation and inhibited by lovastatin. Blood. 2004;104:840-846.

15. Lee SP, Ataga KI, Orringer EP, Parise LV. Biologically active CD40 ligand is elevated in sickle cell disease: potential role for platelet-mediated inflammation. Arterioscler Thromb Vasc. 2006;26:1626-1631.

16. Setty BN, Betal SG, Zhang J, Stuart MJ. Heme induces endothelial tissue factor expression: potential role in hemostatic activation in patients with hemolytic anemia. J Thromb Haemost. 2008;6:2202-2229.

17. Stief TW. The laboratory diagnosis of the pre-phase of pathologic disseminated intravascular coagulation. Hemostasis Laboratory. 2008;1:3-19.

18. Devine DV, Kinney TR, Thomas PF, Rosse WF, Greenberg CS. Fragment D-dimer levels: an objective marker of vaso-occlusive crisis and other complications of sickle cell disease. Blood. 1986;68(1):317-319.

19. Kotila TR, Fawole OI, Shokunbi WA. The role of Haemoglobin F on the clinical severity of sickle cell disease in Nigerian patients. Afr J Med Med Sci. 2000;29:229-231. 
Pathology and Laboratory Medicine International

\section{Publish your work in this journal}

Pathology and Laboratory Medicine International is a peer-reviewed, open access journal focusing on innovative basic research and translational research related to pathology or human disease. The journal includes original research, updates, case reports, reviews and commentaries on current controversies. The Academic Sponsor of this journal is the Chinese American Pathology Association (CAPA). The manuscript management system is completely online and includes a very quick and fair peer-review system. Visit http://www.dovepress.com/testimonials.php to read real quotes from published authors.

Submit your manuscript here: http://www.dovepress.com/pathology-and-laboratory-medicine-international-journal 